\title{
Effect of organic nitrogen concentration on the efficiency of trickling filters
}

\author{
Łukasz Kopeć ${ }^{1, *}$, Jakub Drewnowski ${ }^{2}, F . J$. Fernandez-Morales ${ }^{3}$ \\ ${ }^{1}$ Ekofinn-Pol Ltd, ul. Leśna 12, 80-297 Banino, POLAND \\ ${ }^{2}$ Gdansk University of Technology, Faculty of Civil and Environmental Engineering, \\ Narutowicza 11/12, 80-233 Gdansk, POLAND \\ ${ }^{3}$ Departamento de Ingeniería Química. Instituto de Tecnologías Química y Medioambiental, \\ Universidad de Castilla-La Mancha, Avda. Camilo José Cela s/n. 13004 Ciudad Real.
}

\begin{abstract}
The study was conducted in Poland at six selected wastewater treatment plants (WWTP) based on the trickling filters Bioclere $^{\circledR}$ technology. The aim of the study was to find the relationship between the influent organic nitrogen concentration and the purification efficiency expressed as effluent COD concentration. In the tests performed, the COD to $\mathrm{BOD}_{5}$ relationship was close to 2 and the ratio of $\mathrm{BOD}_{5}$ to $\mathrm{TN}$ was lower than 4. The research indicated that this specific chemical composition of raw wastewater causes appearance of filamentous bacteria on the surface of trickling filter filling and strongly affect the effluent quality.
\end{abstract}

\section{Introduction}

In Poland, the trickling filter technologies are widely used for the treatment of domestic sewage in non-urbanized areas. One of the example of this technology are Bioclere ${ }^{\circledR}$ trickling filters. The main advantages of these devices are the high resistance to biomass wash-out and easy operation under variable wastewater flow-rates. In the trickling filters, the biomass forming the biofilm develops as a result of the scattering of wastewater over the surface of the filling and consists of different microbial species. The species distribution of the biofilm depends primarily on the influent wastewater characteristics. Especially, when the ratio of COD to BOD is greater than 2, undesirable microorganisms grow, such as filamentous bacteria, resulting in deterioration of the effluent quality. When operating trickling filters, as well as in other facilities of this type, little attention is paid to nitrogen compounds, mainly because it is not stablished as one of the main effluent characteristic required to discharge the effluent into the receiving water body. Preliminary studies and observations indicate that the concentration of organic nitrogen, including urea (carbonic acid diamide), has a significant impact on the performance of the trickling filters. The occurrence of very high loading rates of organic nitrogen into the biological treatment could be explained due to the continuous water-saving by the people using the sewage system [1].

* Corresponding author: $1 \mathrm{k} @$ ekofinn.pl 
In this context, the aim of the study was to study the relationship between the influent organic nitrogen concentration and the purification efficiency.

Bioclere $^{\mathbb{B}}$ treatment plants are based on low-rate trickling filter technology. There is Hufo $^{\circledR}$ media inside the reactors. Media is made of polypropylene (PP) and present a great specific surface about $120 \mathrm{~m}^{2} / \mathrm{m}^{3}$. Biofilm, consisting of a mixed culture, grows on media surface. This biofilm preforms the specific reactions removing the pollutants from the wastewater.

In recent years, the number of new Bioclere ${ }^{\circledR}$ treatment plants systematically rise and average about 700 units in Poland. The Biocleres ${ }^{\circledR}$ are good solution for rural areas and work with applications like: scattered households, schools, hotels, restaurants and mountain refugees. It can work in following configurations (the loading is refer to volume of bed as $\left.\mathrm{kg} \mathrm{BOD}_{5} / \mathrm{m}^{3} \cdot \mathrm{d}\right)$ :

1. one-stage unit (basic unit) - run with $0.4 \mathrm{~kg} \mathrm{BOD} / \mathrm{m}^{3} \cdot \mathrm{d}$ and enable to reduce $90 \%$ organic loading (Fig. 1a).

2. two-stage unit without nitrification $-\mathrm{I}^{\circ}$ trickling filter works with $0.8 \mathrm{~kg}$ $\mathrm{BOD}_{5} / \mathrm{m}^{3} \cdot \mathrm{d}$ and $\mathrm{II}^{\circ}$ trickling filter works with $0.4 \mathrm{~kg} \mathrm{BOD} / \mathrm{m}^{3} \cdot \mathrm{d}$. This solution enable to reduce $95 \%$ organic loading (Fig. 1b).

3. two-stage unit with nitrification $-\mathrm{I}^{\circ}$ trickling filter works with $0.4 \mathrm{~kg} \mathrm{BOD} / \mathrm{m}^{3} \cdot \mathrm{d}$ and $\mathrm{II}^{\circ}$ trickling filter with $0.1 \mathrm{~kg} \mathrm{BOD}{ }_{5} / \mathrm{m}^{3} \cdot \mathrm{d}$ and $0,025 \mathrm{kgTN} / \mathrm{m}^{3} \cdot \mathrm{d}$ (nitrification bed). This system can secures organic concentration below $15 \mathrm{mg} \mathrm{O}_{2} / \mathrm{L}$, nitrogen concentration below $6 \mathrm{mgTN} / \mathrm{L}$ and phosphorus loading below $1 \mathrm{mgP} / \mathrm{L}$ (with chemical precipitation).

Bioclere ${ }^{\circledR}$ treatment plants are appropriated for the treatment of domestic wastewater. The chemical constitution of sewage should be: $\mathrm{BOD}_{5}: 200-600 \mathrm{mgO}_{2} / \mathrm{L}$; COD: 700-1200 $\mathrm{mgO}_{2} / \mathrm{L} ; \mathrm{SS}: 200-400 \mathrm{mg} / \mathrm{L}$. According to Heidrich et al. [2] efficient removal is possible when $\mathrm{COD} / \mathrm{BOD}_{5} \leq 2 ; \mathrm{BOD}_{5} / \mathrm{TN} \geq 4$ and $\mathrm{BOD}_{5} / \mathrm{TP} \geq 25$.

\section{Material and methods}

The study was conducted in Poland at six selected wastewater treatment plants (WWTP) based on the trickling filters Bioclere ${ }^{\circledR}$ technology. The research was conducted in the villages of Kwitajny, Protowo (Warmia and Mazury District), Pronie, Gisiel (Pomeranian District), Rządza and Gąsiorowo (Masovian District) for 6 months, from November 2016 to April 2017. The WWTP were configured as two-stage units, with and without secondary sedimentation tank (Tab. 1). Every installation is assigned for service small number of inhabitants (from 75 to 210 people).

Table 1. Characteristic of selected Bioclere ${ }^{\circledR}$ plants (ST - septic tank, TF1 - trickling filter I ${ }^{\circ}$, TF2 trickling filter $\mathrm{II}^{\circ}, \mathrm{SST}-$ secondary sedimentation tank

\begin{tabular}{|r|l|c|c|c|}
\hline No. of object & \multicolumn{1}{|c|}{ Name of plant } & pe & Qav. $\left[\mathrm{m}^{3} / \mathrm{d}\right]$ & Unit System \\
\hline 1. & Kwitajny & 150 & 12 & ST-TF1-TF2-SST \\
\hline 2. & Protowo & 210 & 14 & ST-TF1-TF2-SST \\
\hline 3. & Pronie & 115 & 10 & ST-TF1-TF2 \\
\hline 4. & Gisiel & 115 & 11 & ST-TF1-TF2 \\
\hline 5. & Rządza & 75 & 6 & ST-TF1-TF2-SST \\
\hline 6. & Gąsiorowo & 150 & 20 & ST-TF1-TF2-SST \\
\hline
\end{tabular}

The sewage treatment facilities were characterized by similar capacities and were located in non-urbanized areas. Only wastewater from dwellings and households came to 
these WWTPs. Discharges of other sewage than household were excluded. BOD, COD, ammonia, organic nitrogen (as a measure of urea concentration) and $\mathrm{pH}$ were determined in raw wastewater. Standard methods were used according to [4]. In order to calculate the effectiveness of the purification process for each WWTP, the effluent COD concentration was determined. 12 measurement series were carried out (two per month), and the average concentration values were used for further calculations.

a)
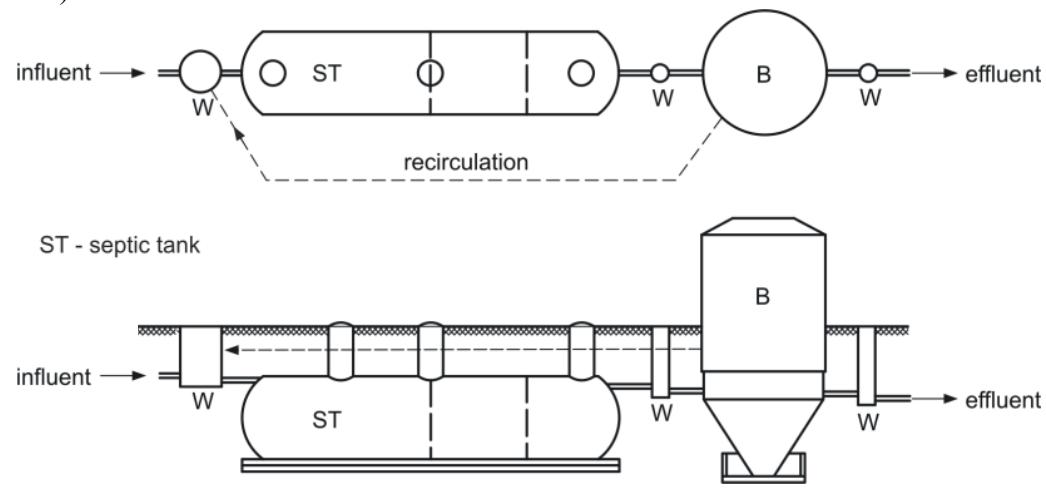

b)
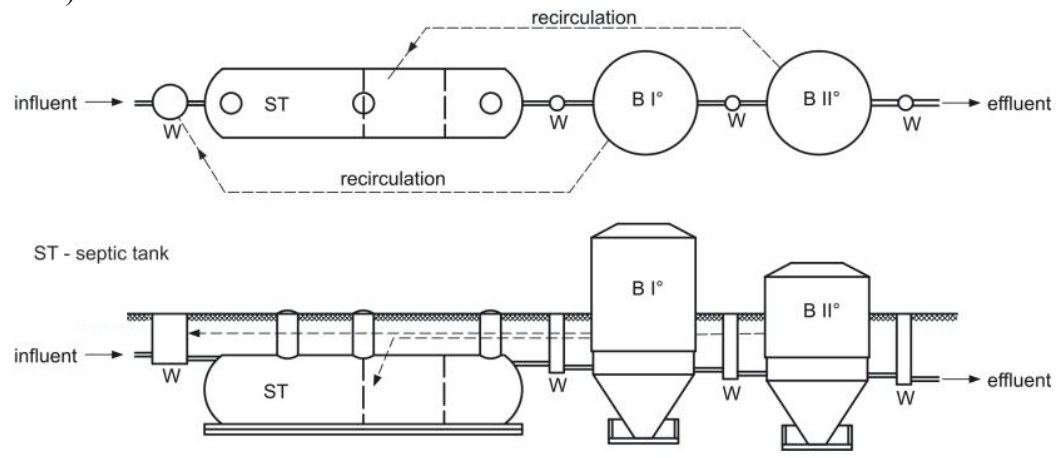

Fig 1. One-stage (a) and two-stages (b) unit applied in Bioclere ${ }^{\circledR}$ trickling filters, $\mathrm{W}-$ inspection chambers; $\mathrm{B} \mathrm{I}^{\circ}, \mathrm{B} \mathrm{II}^{\circ}$ - trickling filters; ST - septic tank [3]

\section{Results and discussion}

Table 2 shows the wastewater characteristics studied in this work. It can be seen that the chemical composition of raw sewage is not the conventional one. As can be seen in Table 2 , the concentration of Kjeldahl nitrogen was too high in all trickling filters to allow its complete removal and therefore to reach a good effluent quality.

Table 2. Values of selected parameters in studied objects. 


\begin{tabular}{|l|c|c|c|c|c|c|c|}
\hline $\begin{array}{l}\text { Name of } \\
\text { plant }\end{array}$ & $\begin{array}{c}\mathrm{BOD}_{5} \\
{[\mathrm{mg} / \mathrm{L}]}\end{array}$ & $\begin{array}{c}\mathrm{COD} \\
{[\mathrm{mg} / \mathrm{L}]}\end{array}$ & $\begin{array}{c}\text { Ammonia } \\
\text { nitrogen } \\
{[\mathrm{mgN} / \mathrm{L}]}\end{array}$ & $\begin{array}{c}\text { Kjeldahl } \\
\text { nitrogen } \\
{[\mathrm{mgN} / \mathrm{L}]}\end{array}$ & $\mathrm{pH}$ & $\begin{array}{c}\mathrm{COD} \\
{[\mathrm{mg} / \mathrm{L}]} \\
(\mathrm{effluent})\end{array}$ & $\begin{array}{c}\mathrm{Q}_{\mathrm{d}} \\
{\left[\mathrm{m}^{3} / \mathrm{d}\right]}\end{array}$ \\
\hline Kwitajny & 210 & 488 & 102 & 112 & 7.2 & 96 & 12 \\
\hline Protowo & 360 & 754 & 105 & 120 & 6.8 & 106 & 14 \\
\hline Pronie & 330 & 612 & 86 & 110 & 6.9 & 150 & 10 \\
\hline Gisiel & 290 & 687 & 107 & 133 & 7.1 & 171 & 11 \\
\hline Rządza & 280 & 564 & 77 & 92 & 7.0 & 112 & 6 \\
\hline Gąsiorowo & 210 & 341 & 60 & 90 & 6.7 & 170 & 20 \\
\hline
\end{tabular}

In all the tests performed, the $\mathrm{COD}$ to $\mathrm{BOD}_{5}$ relationship was close to 2 (Fig. 2), which indicates that the wastewater fed to the trickling filters was hardly biodegradable [5]. The ratio of $\mathrm{BOD}_{5}$ to $\mathrm{TN}$ was much lower than 4 as shown in Figure 3.

Additional, it must be highlighted that the concentrations of organic nitrogen had a significant effect on the effluent COD concentration. WWTP presenting organic nitrogen concentrations above $20 \mathrm{mg} / \mathrm{l}$ at the beginning of the biological treatment were characterized by a nearly doubled COD effluent concentration (Fig. 4). These results indicated that the influent nitrogen concentration clearly influence the effluent quality.

The combination of the low biodegradability and the high concentration of nitrogen compounds leads to changes in the appearance of the biofilm and reduce the quality of the effluent obtained [6]. This chemical composition of raw wastewater causes appearance of filamentous bacteria on the surface of trickling filter filling (Fig. 5a and 5b). Specific chemical composition is the main factor affecting the occurrence of filamentous bacteria [7].

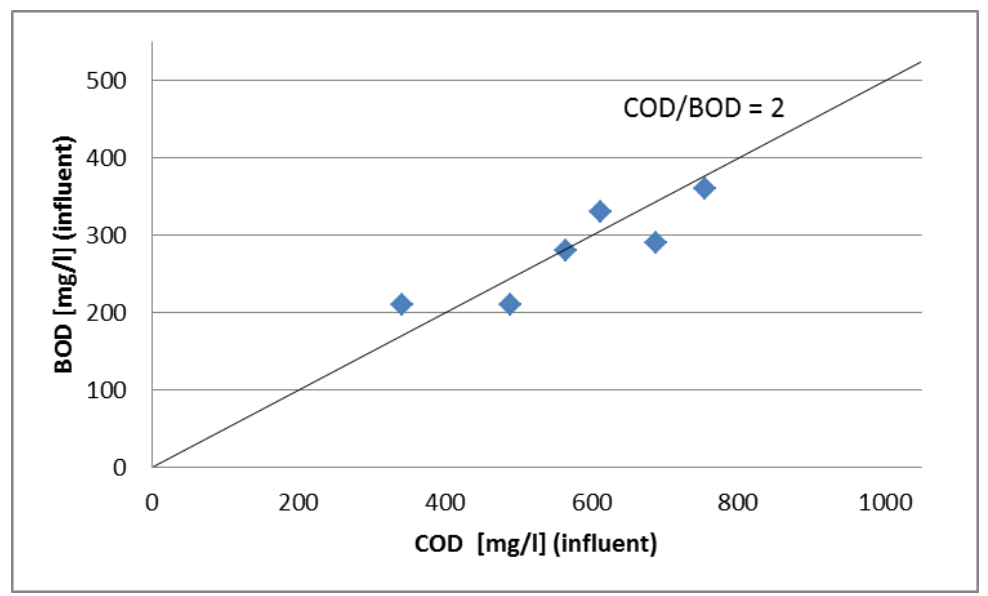

Fig. 2. COD to BOD relationship in the wastewaters studied 


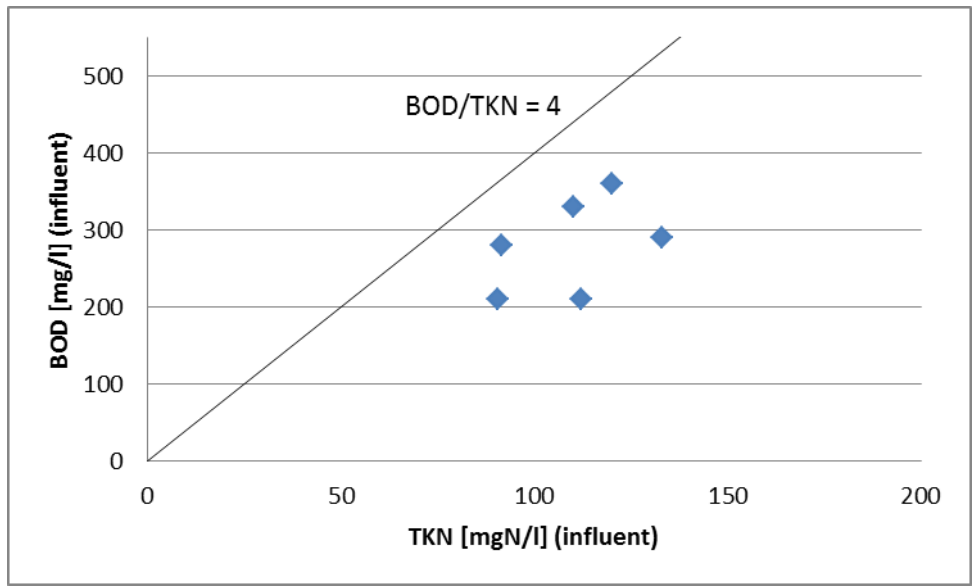

Fig. 3. BOD to TKN relationship in the wastewater studied

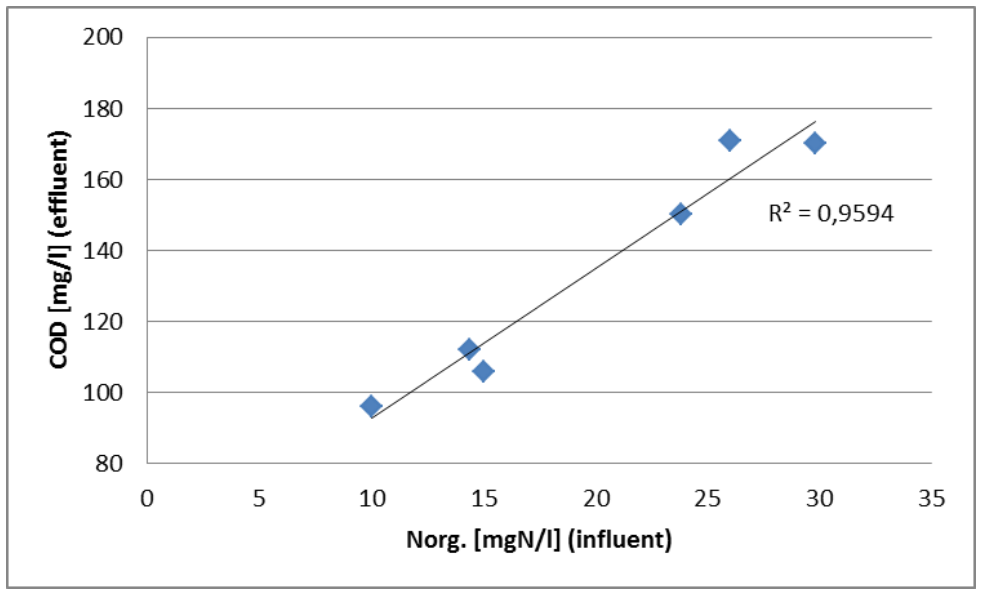

Fig. 4. Effluent COD dependency on the influent organic nitrogen in investigated trickling filters.

a)

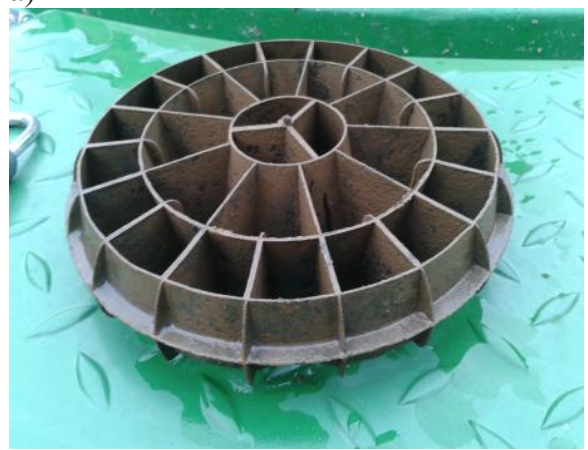

b)

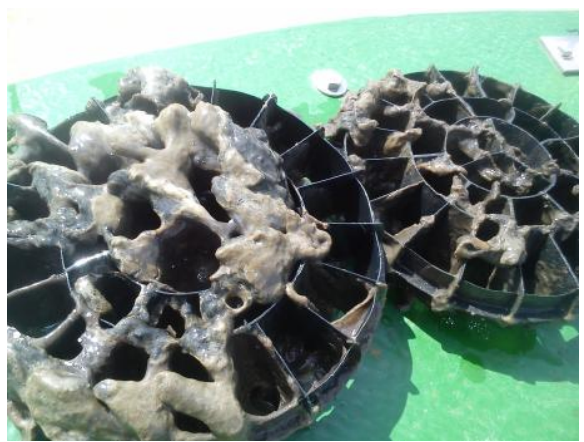

Fig. 5. Shape of trickling filter filling with normal biofilm (a) and with filamentous bacteria (b), (Kopeć 2013)

The investigated research show that the influent sewage contains hardly biodegradable and toxic to most bacteria and protozoa forms of nitrogen. According to the latest sources, 
compounds such as: urea, sulfoamides, antibiotics, analgesics, and other amine-containing pharmaceuticals are present in wastewater $[8,9]$ and would lead to lower qualities in the microbial population degrading these pollutants and therefore in the effluent quality.

\section{Conclusions}

Achieved results show that Bioclere ${ }^{\circledR}$ trickling filters are able to effective removal of pollutants from wastewater to the allowable effluent values. The exceptions to the properly functioning trickling filter plants are related to the unbalanced proportions in the chemical composition of the influent wastewater. Especially disproportionate is the $\mathrm{BOD}_{5}$ to total nitrogen compounds, including organic nitrogen. The presence of high organic nitrogen levels in the influent wastewater leads to a process where some pollutants are not removed, getting the effluent and degrading its quality.

The causes of high amount of nitrogen must lie in the behavior of people and how their use of the sewerage network. People in rural areas in Poland have low water consumption, so raw sewage is more concentrated and easier to rotting.

The results of the article confirm the possibility of large quantities of harmful substances for bacteria in sewage in non-urbanized areas. However, the determination of impact of these compounds on the effectiveness of purification based only on organic nitrogen concentrations is insufficient. Further research should be extended by chemical analyzes of specific substances which are present in wastewater and slow down biochemical processes.

Acnowledgements: Ekofinn-Pol Ltd., Poland, for accessing Bioclere ${ }^{\circledR}$ trickling filters.

\section{References}

1. M. Gajewska, Ł. Kopeć , H. Obarska-Pempkowiak. The operation of a small wastewater treatment facilities in a scattered settlement. Rocz. Ochr. Środ., 13, 207225 (2011)

2. Z. Heidrich, M. Kalenik, J. Podedworna, G. Stańko Sanitacja wsi. Wyd. „SeidelPrzywecki. Warszawa. (2008).

3. Ekofinn-Pol Ltd., Information materials, 36, (2015).

4. APHA. Standard Methods for the Examination of Water and Wastewater, 18th edn. American Public Health Association/ American Water Works Association/Water Environment Federation, Washington, DC, USA, (1992).

5. Z. Dymaczewski Poradnik eksploatatora oczyszczalni ścieków - praca zbiorowa. Polskie Zrzeszenie Inżynierów i Techników, Poznań, 1152, (2011).

6. Ł. Kopeć, Mikroorganizmy błony biologicznej w złożach zraszanych. Gaz, Woda i Technika Sanitarna, 2, 53-58. (2013).

7. S. Rossetti, C. Maria, M.C. Tomei, P.H. Nielsen, V. Tandoi “'Microthrix parvicella", a filamentous bacterium causing bulking and foaming in activated sludge systems: a review of current knowledge. FEMS Microbiology Reviews 29, 49-64. (2005)

8. B. Kraigher, T. Kosjek, E. Heath, B. Kompare, I. Mandic-Mulec. Influence of pharmaceutical residues on the structure of activated sludge bacterial communities in wastewater treatment bioreactors. Water Research 42, (2008).

9. T. Heberer. Occurrence, fate and removal of pharmaceutical residues in the aquatic environment: a review of recent research data. Toxicology Letters, 131, (2002). 